ISSN 0258-7122 (Print), 2408-8293 (Online)

Bangladesh J. Agril. Res. 42(3): 509-520, September 2017

\title{
SYSTEM PRODUCTIVITY, NUTRIENT UPTAKE AND NUTRIENT BALANCE IN THE WHEAT-MUNGBEAN-T. AMAN RICE CROPPING SYSTEM
}

\author{
M. A. QUDDUS ${ }^{1}$, J. A. MIAN ${ }^{2}$, M. A. HASHEM ${ }^{3}$ \\ H. M. NASER ${ }^{4}$ AND M. A. HOSSAIN ${ }^{5}$
}

\begin{abstract}
System productivity, nutrient uptake and apparent nutrient balance in the wheatmungbean-T. aman rice cropping system was studied. The experiment comprised four treatments-absolute nutrient control $\left(\mathrm{T}_{1}\right)$; farmer's practice $\left(\mathrm{T}_{2}\right)$; AEZ basis fertilizer application $\left(\mathrm{T}_{3}\right)$ and soil test basis fertlizer application $\left(\mathrm{T}_{4}\right)$. The treatments were compared in a RCBD with three replications over two consecutive years, 2008-09 and 2009-10. The experiment was conducted in Chhiata clay loam soil. The average yields of wheat, mungbean and T. aman ranged from 1415 to $3096 \mathrm{~kg} \mathrm{ha}^{-1}, 1020$ to $1463 \mathrm{~kg} \mathrm{ha}^{-1}$ and 2999 to $4282 \mathrm{~kg} \mathrm{ha}$ 1 , respectively showing $\mathrm{T}_{4}$ as the best treatment. The same treatment $\left(\mathrm{T}_{4}\right)$ demonstrated the highest nutrient uptake by the crops. The apparent balance of $\mathrm{N}$ and $\mathrm{K}$ (difference between nutrient uptake and nutrient addition) was negative; however it was less negative for $\mathrm{T}_{4}$ treatment. The $\mathrm{P}$ balance was positive for all the treatment except $T_{1}$. Positive $S$ balance was observed in $T_{3}$ and $\mathrm{T}_{4}$ but negative in absolute control and farmer's practice. Zinc and $\mathrm{B}$ balance was also positive in case of $\mathrm{T}_{3}$ and $\mathrm{T}_{4}$, but negative for $\mathrm{T}_{1}$ and $\mathrm{T}_{2}$ except B. The study suggests soil test basis fertlizer recommendation for the wheatmungbean-T. aman rice cropping system.
\end{abstract}

Keywords: System productivity, nutrient uptake, nutrient balance, wheatmungbean-T. aman rice.

\section{Introduction}

Cropping system in an area depends largely on agro-climatic, technical and institutional factors. Several studies have shown that intensive rice-based cropping system including rice-wheat (RW) causes remarkable depletion of soil nutrients and threat to crop productivity (Timsina and Connor, 2001; YadvinderSingh et al., 2005). Besides the farmers are following imbalanced use of fertilizers for crop production which leads to degrade soil fertility (Ali et al., 2010). Farmers generally use fertilizers on single crop basis, not the cropping system. High yielding varieties of crops uptake higher amount of nutrients from soils resulting in depletion of soil organic matter and deterioration of soil fertility, poses a great threat to sustainable crop production. Moreover, continuous

${ }^{1}$ Senior Scientific Officer, Horticulture Research Centre, Bangladesh Agricultural Research Institute (BARI), Gazipur, ${ }^{5}$ Principal Scientific Officer, PRSS, BARI, Gazipur, ${ }^{4}$ Principal Scientific Officer, Soil Science Division, BARI, Gazipur, ${ }^{2,3}$ Professor, Department of Soil Science, BAU, Mymensingh, Bangladesh. 
cropping without adequate replacement of removed nutrients and nutrient loss through erosion, leaching, and gaseous emission have caused depletion soil fertility as well as soil organic matter (Tirol-Padre et al., 2007). The bulk of literature indicates that, apart from residue management, cropping system productivity may become sustainable through integrated use of organic and inorganic sources of nutrients (Singh and Yadav, 1992). Hence, it is important to develop a cropping system based fertilizer dose for specific agro-ecological zone. Quantification of the loss or gain of nutrients under different cropping system has been less attended. Nutrient balance is an important tool for assessing the nutrient reserve in soils. Crop nutrient balance is a differences between nutrients applied to soil in relation to its removal by crops. Negative nutrient balance may limit crop yield and deplete soil fertility and positive nutrient balance shows nutrient accumulation and creates a risk of water and air pollution (Paul Fixen et al., 2014). It is hypothised that the current fertilizer recommendation could be improved for a definite cropping system. Thus, the aim of this study was to compare system productivity, nutrient uptake and nutrient balance for the wheatmungbean-T. aman rice cropping system with varying fertilizer management practices.

\section{Materials and Method}

Experiment with wheat-mungbean-T. aman rice cropping system was conducted for consecutive two years (2008-09 and 2009-10) at Pulses Research Sub-Station, BARI, Gazipur ( $24^{\circ} 0^{\prime} 13^{\prime \prime} \mathrm{N}$ latitude and $90^{\circ} 25^{\prime} 0^{\prime \prime} \mathrm{E}$ longitude) which lies at an elevation of $8.4 \mathrm{~m}$ above the sea level. The crop field was medium high land with clay loam soil and it belongs to Chhiata series (Soil taxonomy: Udic Rhodustalf) under the agroecological zone Madhupur Tract (AEZ-28).

The experiment consisted of four treatments-absolute nutrient controls $\left(\mathrm{T}_{1}\right)$; farmer's practice $\left(\mathrm{T}_{2}\right)$; AEZ basis fertilizer application $\left(\mathrm{T}_{3}\right)$ and soil test basis fertlizer application $\left(\mathrm{T}_{4}\right)$. Descriptions of the different treatments are given in Table 1 .

Table 1. Rates of fertilizers $\left(\mathrm{kg} \mathrm{ha}^{-1}\right)$ for wheat, mungbean and T. aman

\begin{tabular}{cll|l|l}
\hline Treatments & Wheat & Mungbean & T. aman \\
\hline $\mathrm{T}_{1}$ & Control & Control & Control \\
$\mathrm{T}_{2}$ & $\mathrm{~N}_{80} \mathrm{P}_{20} \mathrm{~K}_{30}$ & $\mathrm{~N}_{6} \mathrm{P}_{5} \mathrm{~K}_{4}$ & $\mathrm{~N}_{60} \mathrm{P}_{6} \mathrm{~K}_{20}$ \\
$\mathrm{~T}_{3}$ & $\mathrm{~N}_{90} \mathrm{P}_{20} \mathrm{~K}_{60} \mathrm{~S}_{10} \mathrm{Zn}_{0} \mathrm{~B}_{1}$ & $\mathrm{~N}_{7} \mathrm{P}_{7} \mathrm{~K}_{5}$ & $\mathrm{~N}_{65} \mathrm{P}_{7} \mathrm{~K}_{28} \mathrm{~S}_{8} Z_{n_{1}}$ \\
$\mathrm{~T}_{4}$ & $\mathrm{~N}_{110} \mathrm{P}_{25} \mathrm{~K}_{70} \mathrm{~S}_{23} \mathrm{Zn}_{2} \mathrm{~B}_{1}$ & $\mathrm{~N}_{15} \mathrm{P}_{20} \mathrm{~K}_{10} \mathrm{~S}_{6} \mathrm{Zn}_{1} \mathrm{~B}_{1}$ & $\mathrm{~N}_{70} \mathrm{P}_{12} \mathrm{~K}_{40} \mathrm{~S}_{10} \mathrm{Zn}_{1} \mathrm{~B}_{1}$ \\
\hline
\end{tabular}

Subscripts represent $\mathrm{kg} \mathrm{ha}^{-1}$

The experiment was laid out in a randomized complete block design (RCBD) with three replications. The unit plot size was $4 \mathrm{~m} \times 3 \mathrm{~m}$ for all crops having a spacing of $30 \mathrm{~cm} \times 10 \mathrm{~cm}$ for wheat, $30 \mathrm{~cm} \times 10 \mathrm{~cm}$ for mungbean and $20 \mathrm{~cm} \times$ $15 \mathrm{~cm}$ for T. aman rice. Full amount of fertilizers except urea in wheat and rice was applied to crop during final land preparation. Urea was applied in two equal splits for 
wheat and three equal splits for T. aman rice. The sources of N, P, K, S, Zn and B were urea, triple superphosphate, muriate of potash, gypsum, zinc sulphate and boric acid, respectively. Wheat (var. BARI Gom-24) seeds were sown on 15 November 2008 and 11 November 2009. Mungbean (BARI Mung-6) seeds were sown on 26 March 2009 and 20 March 2010. T.aman rice (var. BRRI dhan33) seedlings (30 days old) were transplanted on 15 July 2009 and 18 July 2010. Intercultural operations were done as and when required. The crops were harvested at maturity. Data on yields $\left(\mathrm{kg} \mathrm{ha}^{-1}\right)$ for all test crops were recorded from whole plot. Analysis of variance (ANOVA) for the yields and different nutrient content was done following the principle of F-statistics and the mean values were separated by DMRT (Gomez and Gomez, 1984) at 5\% level of probability using MSTATC software.

Soil samples at $0-15 \mathrm{~cm}$ were collected before establishing the experiment and after completion of two cycles of the cropping system from each treatment plot. Plant samples (straw and grain) against each treatment plot were oven-dried at $70^{\circ} \mathrm{C}$ for $48 \mathrm{~h}$ and finely ground. The initial and final soil samples were analyzed for soil $\mathrm{pH}$ and organic matter by Nelson and Sommers (1982) method; total $\mathrm{N}$ by Microkjeldahl method (Bremner and Mulvaney, 1982); exchangeable K by $1 \mathrm{~N} \mathrm{NH}_{4} \mathrm{OAc}$ method (Jackson, 1973); available P by Olsen and Sommers (1982) method; available $\mathrm{S}$ by turbidity method using $\mathrm{BaCl}_{2}$ (Fox et al., 1964); available Zn by DTPA method (Lindsay and Norvell, 1978); available B by azomethine-H method (Page et al., 1982). Ground plant samples were digested with di-acid mixture $\left(\mathrm{HNO}_{3}-\mathrm{HClO}_{4}\right)(5: 1)$ as described by Piper (1966) for the determinationconcentration of $\mathrm{N}$ (Micro-Kjeldahl method), $\mathrm{P}$ (spectrophotometer method), $\mathrm{K}$ (atomic absorption spectrophotometer method), $\mathrm{S}$ (turbidity method using $\mathrm{BaCl}_{2}$ by spectrophotometer), Zn (atomic absorption spectrophotometer method) and B (spectrophotometer following azomethine-H method). Rain and irrigation water samples were analysed for concentration of $\mathrm{P}, \mathrm{K}, \mathrm{S}, \mathrm{Zn}$ and $\mathrm{B}$ same as plant samples method.

Crop nutrient uptake was calculated from the nutrient (N, P, K, S, Zn and B) concentration and the straw and grain yields (Quayyum et al., 2002). Apparent nutrient balance for the wheat-mungbean- $T$. aman rice cropping system (average of two years) was computed as the difference between nutrient input and output (Paul Fixen et al., 2014). The inputs were supplied from (i) fertilizer (ii) rainfall and (iii) irrigation water and the outputs were estimated from crop uptake in a cycle.

Added cost and added benefit were calculated. Besides, the gross return was calculated on the basis of different treatments which were directly related to the price of product. Cost of cultivation was involved with wage rate (land preparation, weeding, seed sowing and fertilizers application), pesticides, irrigation and fertilizers cost. Land used cost or rental value of land was not considered here. Marginal benefit cost ratio (MBCR) is the ratio of marginal or 
added benefit and cost. To compare different treatments combination with one control treatment the following equation was applied (Rahman et al., 2011).

$$
\begin{aligned}
\operatorname{MBCR}(\text { over control }) & =\frac{\text { Gross return }(\mathrm{Ti})-\text { Gross return }(\mathrm{To})}{\mathrm{VC}(\mathrm{Ti})-\mathrm{VC}(\mathrm{To})} \\
& =\frac{\text { Added benefit }(\text { overcontrol })}{\text { Added cost }(\text { overcontrol })}
\end{aligned}
$$

Where, $\mathrm{T}_{\mathrm{i}}=\mathrm{T}_{2}, \ldots \ldots \ldots \mathrm{T}_{4}$ treatments; $\mathrm{T}_{0}=$ Control treatment; $\mathrm{VC}=$ Variable cost; and Gross return $=$ Yield $\times$ price

\section{Results and Discussion}

\section{Crops yield}

Nutrient management practices significantly influenced the grain and straw/stover yields of wheat, mungbean and $\mathrm{T}$. aman rice in every year (Table 2). The control $\left(\mathrm{T}_{1}\right)$ treatment gave the lowest grain yield of 1415,1020 and $2999 \mathrm{~kg}$ $\mathrm{ha}^{-1}$ (mean of two years) in wheat, mungbean and T. aman rice, respectively. The farmers practice of fertilizer application $\left(T_{2}\right)$ increased grain yield to $2201 \mathrm{~kg} \mathrm{ha}^{-1}$ in wheat, $1222 \mathrm{~kg} \mathrm{ha}^{-1}$ in mungbean and $3556 \mathrm{~kg} \mathrm{ha}^{-1}$ in T. aman rice. Fertilizer dose on AEZ basis $\left(\mathrm{T}_{3}\right)$ resulted in further yield increased of $2787 \mathrm{~kg} \mathrm{ha}^{-1}$ in wheat, $1346 \mathrm{~kg} \mathrm{ha}^{-1}$ in mungbean and $3914 \mathrm{~kg} \mathrm{ha}^{-1}$ in T. aman rice. The $\mathrm{T}_{4}$ treatment (soil test basis fertilizer application) gave the highest crop yields for all the test crops (Table 2). In case of straw/stover yield, the treatments generally statistically differed with one another. The highest value being noted in $T_{4}$ treatment. The reasons of yield increase due to fertilizer management might be attributed to deficency of soil nutrients, particularly $\mathrm{N}$ and $\mathrm{K}$. The percent grain yields of wheat, mungbean and $\mathrm{T}$. aman rice increased over control due to different nutrient management practices were 55 to $119 \%, 20$ to $43 \%$ and 19$43 \%$, respectively. Islam et al (1996) also reported $42 \%$ yield increase of rice over control due to balanced fertilization. Most of the yield contributing characters of wheat, mungbean and $\mathrm{T}$. aman rice highly responded to soil test basis fertilization $\left(\mathrm{T}_{4}\right)$ followed by AEZ basis fertilization $\left(\mathrm{T}_{3}\right)$.

\section{Nutrient uptake}

Nutrient management practices had significant effect on the uptake of N, P, K, S, $\mathrm{Zn}$ and $\mathrm{B}$ by the crops in wheat-mungbean-T.aman rice cropping system in both the years (Table 3). Fertlizer application on soil test basis $\left(\mathrm{T}_{4}\right)$ showed significantly higher nutrient uptake by wheat, mungbean and $\mathrm{T}$. aman rice in both the years. The nutrient uptake followed the order: $\mathrm{N}>\mathrm{K}>\mathrm{P}>\mathrm{S}>\mathrm{Zn}>\mathrm{B}$. The lower nutrient uptake was found in control $\left(\mathrm{T}_{1}\right)$ treatment by all test crops. The total uptake of nutrients by crops (wheat+mungbean+T. aman rice) ranged from 160- 
$260 \mathrm{~kg} \mathrm{~N} \mathrm{ha}^{-1}, 17.4-32.0 \mathrm{~kg} \mathrm{P} \mathrm{ha}^{-1}, 132-194 \mathrm{~kg} \mathrm{~K} \mathrm{ha}^{-1}, 9.05-17.6 \mathrm{~kg} \mathrm{~S}^{-1}$, 0.47$0.79 \mathrm{~kg} \mathrm{Zn} \mathrm{ha}^{-1}$ and $0.23-0.40 \mathrm{~kg} \mathrm{~B} \mathrm{ha}^{-1}$ (Table 4).

Table 2. Effects of nutrient management practices on grain and straw/stover yields of crops in the wheat-mungbean-T. aman rice cropping system

\begin{tabular}{|c|c|c|c|c|c|c|c|}
\hline \multirow[b]{2}{*}{ Treatment } & \multicolumn{4}{|c|}{ Grain yield $\left(\mathrm{kg} \mathrm{ha}^{-1}\right)$} & \multicolumn{3}{|c|}{ Straw/stover yield $\left(\mathrm{kg} \mathrm{ha}^{-1}\right)$} \\
\hline & 2009 & 2010 & mean & $\begin{array}{c}\% \text { increase } \\
\text { over control }\end{array}$ & 2009 & 2010 & mean \\
\hline \multicolumn{8}{|c|}{ Wheat } \\
\hline Control $\left(\mathrm{T}_{1}\right)$ & $1251 d$ & $1580 \mathrm{~d}$ & 1415 & - & 1984d & $2345 d$ & 2164 \\
\hline F. practice $\left(T_{2}\right)$ & $2088 \mathrm{c}$ & $2314 \mathrm{c}$ & 2201 & 55 & $2510 \mathrm{c}$ & $2800 c$ & 2655 \\
\hline $\operatorname{AEZ}\left(T_{3}\right)$ & $2565 b$ & $3010 \mathrm{~b}$ & 2787 & 97 & $3136 \mathrm{~b}$ & $3612 b$ & 3374 \\
\hline $\mathrm{STB}\left(\mathrm{T}_{4}\right)$ & $2898 \mathrm{a}$ & $3294 a$ & 3096 & 119 & $3454 a$ & 3910a & 3682 \\
\hline $\mathrm{CV}(\%)$ & 2.99 & 2.35 & - & - & 3.32 & 2.37 & - \\
\hline \multicolumn{8}{|c|}{ Mungbean } \\
\hline Control $\left(\mathrm{T}_{1}\right)$ & $1038 \mathrm{~d}$ & $1003 d$ & 1020 & - & $2156 d$ & $2124 b$ & 2140 \\
\hline F. practice $\left(T_{2}\right)$ & $1229 c$ & $1216 \mathrm{c}$ & 1222 & 20 & $2274 \mathrm{c}$ & $2235 \mathrm{ab}$ & 2255 \\
\hline $\operatorname{AEZ}\left(\mathrm{T}_{3}\right)$ & $1359 b$ & $1332 b$ & 1346 & 32 & $2410 \mathrm{~b}$ & $2389 \mathrm{ab}$ & 2400 \\
\hline $\mathrm{STB}\left(\mathrm{T}_{4}\right)$ & $1485 \mathrm{a}$ & $1440 \mathrm{a}$ & 1463 & 43 & 2531a & $2500 \mathrm{a}$ & 2516 \\
\hline $\mathrm{CV}(\%)$ & 3.65 & 2.87 & - & - & 4.23 & 4.69 & - \\
\hline \multicolumn{8}{|c|}{ T. aman } \\
\hline Control $\left(\mathrm{T}_{1}\right)$ & $3022 c$ & 2976d & 2999 & - & $3137 d$ & $3134 \mathrm{c}$ & 3135 \\
\hline F. practice $\left(T_{2}\right)$ & $3521 b$ & $3591 \mathrm{c}$ & 3556 & 19 & $3736 c$ & $3753 c$ & 3744 \\
\hline $\operatorname{AEZ}\left(\mathrm{T}_{3}\right)$ & $3908 b$ & $3920 \mathrm{~b}$ & 3914 & 31 & $4070 \mathrm{~b}$ & 4094b & 4082 \\
\hline $\operatorname{STB}\left(\mathrm{T}_{4}\right)$ & $4224 a$ & $4341 \mathrm{a}$ & 4282 & 43 & $4352 a$ & $4443 a$ & 4397 \\
\hline $\mathrm{CV}(\%)$ & 3.83 & 3.94 & - & - & 3.72 & 4.74 & - \\
\hline
\end{tabular}

Values within a column with a common letter do not differ significantly $(\mathrm{p}=0.05)$ by DMRT.

The maximum $\mathrm{N}$ uptake was found in STB $\left(260 \mathrm{~kg} \mathrm{ha}^{-1} \mathrm{yr}^{-1}\right)$ followed by AEZ $\left(\mathrm{T}_{3}\right)$. This finding is in agreement with the findings of Timsina et al. (2006) where N uptake was consistently and significantly greater under STB than in FP fertilizer management. The minimum $\mathrm{N}$ uptake was estimated in control. Shrestha and Ladha (2001) reported that N uptake by sweet pepper-fallow-rice, sweet pepper-indigo-rice, sweet pepper-indigo + mungbean-rice and sweet pepper-corn-rice were $241,390,358$ and $411 \mathrm{~kg} \mathrm{~N} \mathrm{ha}^{-1} \mathrm{yr}^{-1}$, respectively. The uptake of other nutrients $(\mathrm{P}, \mathrm{K}, \mathrm{S}, \mathrm{Zn}$ and $\mathrm{B})$ due to different nutrient management practices followed almost the same trend of $\mathrm{N}$ uptake (Saleque et al., 2006; Debnath et al., 2011). 
Table 3. Effects of nutrient management practices on nutrient uptake ( $\left.\mathrm{kg} \mathrm{ha}^{-1}\right)$ by wheat-mungbean-T. aman rice (grain+straw/stover) cropping system

\begin{tabular}{|c|c|c|c|c|c|c|c|c|c|c|c|c|}
\hline \multirow{2}{*}{ Treatment } & \multicolumn{2}{|c|}{$\mathrm{N}$} & \multicolumn{2}{|c|}{$\mathrm{P}$} & \multicolumn{2}{|c|}{$\mathrm{K}$} & \multicolumn{2}{|c|}{ S } & \multicolumn{2}{|c|}{$\mathrm{Zn}$} & \multicolumn{2}{|c|}{ B } \\
\hline & $1^{\mathrm{st}} \mathrm{yr}$ & $2^{\text {nd }} \mathrm{yr}$ & $1^{\text {st }} \mathrm{yr}$ & $2^{\text {nd }} \mathrm{yr}$ & $1^{\text {st }} \mathrm{yr}$ & $2^{\text {nd }} \mathrm{yr}$ & $1^{\mathrm{st}} \mathrm{yr}$ & $2^{\text {nd }} \mathrm{yr}$ & $1^{\mathrm{st}} \mathrm{yr}$ & $2^{\text {nd }} y r$ & $1^{\text {st }} \mathrm{yr}$ & $2^{\text {nd }} y r$ \\
\hline \multicolumn{13}{|c|}{ Wheat } \\
\hline Control $\left(\mathrm{T}_{1}\right)$ & $33.6 \mathrm{~d}$ & $40.9 \mathrm{~d}$ & $4.75 d$ & $5.20 \mathrm{~d}$ & $26.5 \mathrm{~d}$ & $31.2 \mathrm{~d}$ & $2.51 \mathrm{c}$ & $2.67 \mathrm{c}$ & $0.15 d$ & $0.18 \mathrm{~d}$ & $0.09 \mathrm{~d}$ & $0.08 \mathrm{~d}$ \\
\hline $\begin{array}{l}\text { F. practice } \\
\left(\mathrm{T}_{2}\right)\end{array}$ & $54.2 \mathrm{c}$ & $59.5 c$ & $8.00 \mathrm{c}$ & $8.3 \mathrm{c}$ & $36.1 \mathrm{c}$ & $39.7 \mathrm{c}$ & $3.85 b$ & $3.76 \mathrm{~b}$ & $0.22 \mathrm{c}$ & $0.24 \mathrm{c}$ & $0.11 \mathrm{c}$ & $0.12 \mathrm{c}$ \\
\hline $\operatorname{AEZ}\left(\mathrm{T}_{3}\right)$ & $68.0 \mathrm{~b}$ & $78.8 \mathrm{~b}$ & $10.4 b$ & $11.2 \mathrm{~b}$ & $45.5 b$ & $52.0 \mathrm{~b}$ & $5.33 \mathrm{a}$ & $5.54 \mathrm{a}$ & $0.28 b$ & $0.33 b$ & $0.14 b$ & $0.16 \mathrm{~b}$ \\
\hline $\mathrm{STB}\left(\mathrm{T}_{4}\right)$ & $78.5 \mathrm{a}$ & $88.0 \mathrm{a}$ & $12.6 \mathrm{a}$ & $13.3 \mathrm{a}$ & $51.4 \mathrm{a}$ & $57.5 \mathrm{a}$ & $6.59 a$ & $6.75 \mathrm{a}$ & $0.33 \mathrm{a}$ & $0.37 \mathrm{a}$ & $0.16 \mathrm{a}$ & $0.18 \mathrm{a}$ \\
\hline CV (\%) & 2.14 & 2.36 & 8.73 & 7.65 & 5.06 & 4.52 & 8.16 & 7.14 & 5.41 & 6.11 & 8.71 & 7.56 \\
\hline \multicolumn{13}{|c|}{ Mungbean } \\
\hline Control $\left(\mathrm{T}_{1}\right)$ & $60.2 \mathrm{~d}$ & $58.0 \mathrm{~d}$ & $5.92 \mathrm{c}$ & $5.47 \mathrm{~d}$ & $61.7 \mathrm{~d}$ & $59.9 \mathrm{~d}$ & $2.01 \mathrm{~b}$ & $1.65 c$ & 0.08 & 0.07 & 0.06 & 0.05 \\
\hline $\begin{array}{l}\text { F.practice } \\
\left(\mathrm{T}_{2}\right)\end{array}$ & $68.5 c$ & $67.1 \mathrm{c}$ & $6.90 \mathrm{bc}$ & $6.40 \mathrm{c}$ & $67.6 \mathrm{c}$ & $66.1 \mathrm{c}$ & $2.47 b$ & $2.09 \mathrm{~b}$ & 0.09 & 0.08 & 0.06 & 0.06 \\
\hline $\operatorname{AEZ}\left(\mathrm{T}_{3}\right)$ & $75.5 b$ & $73.6 \mathrm{~b}$ & $7.80 \mathrm{~b}$ & $7.10 \mathrm{~b}$ & $72.9 \mathrm{~b}$ & $71.5 b$ & $3.05 \mathrm{a}$ & $2.39 a$ & 0.09 & 0.09 & 0.07 & 0.07 \\
\hline $\mathrm{STB}\left(\mathrm{T}_{4}\right)$ & $82.7 \mathrm{a}$ & $80.0 \mathrm{a}$ & $8.50 \mathrm{a}$ & $7.90 \mathrm{a}$ & $78.3 \mathrm{a}$ & $76.1 \mathrm{a}$ & $3.51 \mathrm{a}$ & $2.80 \mathrm{a}$ & 0.11 & 0.10 & 0.08 & 0.07 \\
\hline CV (\%) & 2.43 & 3.11 & 6.69 & 4.35 & 1.23 & 2.35 & 9.23 & 8.54 & 7.04 & 6.95 & 8.19 & 7.20 \\
\hline \multicolumn{13}{|c|}{ T. aman } \\
\hline Control $\left(\mathrm{T}_{1}\right)$ & $63.9 \mathrm{~d}$ & $62.1 \mathrm{~d}$ & $7.04 \mathrm{c}$ & $6.36 c$ & $42.7 \mathrm{~d}$ & $41.3 \mathrm{~d}$ & $5.24 \mathrm{c}$ & $3.98 \mathrm{c}$ & $0.23 \mathrm{~d}$ & $0.24 d$ & $0.11 d$ & $0.10 \mathrm{c}$ \\
\hline $\begin{array}{l}\text { F.practice } \\
\left(\mathrm{T}_{2}\right)\end{array}$ & $76.2 \mathrm{c}$ & $76.5 \mathrm{c}$ & $9.00 \mathrm{~b}$ & $8.40 \mathrm{~b}$ & $51.7 \mathrm{c}$ & $51.0 \mathrm{c}$ & $6.53 b$ & $5.88 \mathrm{~b}$ & $0.27 \mathrm{c}$ & $0.28 \mathrm{c}$ & $0.12 \mathrm{c}$ & $0.11 b$ \\
\hline $\operatorname{AEZ}\left(\mathrm{T}_{3}\right)$ & $84.8 b$ & $84.3 b$ & $9.50 \mathrm{~b}$ & $8.70 \mathrm{~b}$ & $57.4 \mathrm{~b}$ & $56.9 \mathrm{~b}$ & $7.20 \mathrm{ab}$ & $6.02 \mathrm{~b}$ & $0.31 b$ & $0.30 \mathrm{~b}$ & $0.15 b$ & $0.16 \mathrm{a}$ \\
\hline $\mathrm{STB}\left(\mathrm{T}_{4}\right)$ & $94.7 \mathrm{a}$ & $95.0 \mathrm{a}$ & $11.1 \mathrm{a}$ & $10.5 \mathrm{a}$ & $62.3 \mathrm{a}$ & $62.8 \mathrm{a}$ & $8.15 a$ & $7.47 \mathrm{a}$ & $0.33 \mathrm{a}$ & $0.34 \mathrm{a}$ & $0.16 \mathrm{a}$ & $0.17 \mathrm{a}$ \\
\hline CV (\%) & 1.95 & 1.26 & 6.27 & 5.89 & 1.21 & 1.09 & 6.50 & 5.89 & 4.04 & 3.33 & 3.85 & 4.97 \\
\hline
\end{tabular}

Values within a column with a common letter do not differ significantly $(p=0.05)$ by DMRT.

Table 4. Effects of fertilizer management practices on total nutrients uptake by crops in the wheat-mungbean- $T$. aman rice cropping system (mean of two years)

\begin{tabular}{l|c|c|c|c|c|c}
\hline \multicolumn{1}{c|}{ Treatment } & $\mathrm{N}$ & $\mathrm{P}$ & $\mathrm{K}$ & $\mathrm{S}$ & $\mathrm{Zn}$ & $\mathrm{B}$ \\
\hline \multicolumn{7}{c}{$\mathbf{k g ~ h a}^{-1}$} \\
Control $\left(\mathrm{T}_{1}\right)$ & 160 & 17.4 & 132 & 9.05 & 0.47 & 0.23 \\
F. practice $\left(\mathrm{T}_{2}\right)$ & 201 & 23.5 & 156 & 12.3 & 0.59 & 0.28 \\
AEZ $\left(\mathrm{T}_{3}\right)$ & 233 & 27.4 & 178 & 14.8 & 0.70 & 0.37 \\
STB $\left(\mathrm{T}_{4}\right)$ & 260 & 32.0 & 194 & 17.6 & 0.79 & 0.40 \\
\hline
\end{tabular}




\section{Total input of nutrients}

The nutrient input was mainly from fertilizer but in this estimate, the nutrients supply from fertilizer, rainfall and irrigation under wheat-mungbean-T. aman rice cropping system. BNF was not considerd. Total input of nitrogen was 146-195 kg $\mathrm{N} \mathrm{ha}^{-1}$ of which the major part was added through fertilizer application, except in control treatment. Phosphorus input ranged from 0.48 to $57.5 \mathrm{~kg} \mathrm{ha}^{-1} \mathrm{yr}^{-1}$ and $\mathrm{K}$ from 9.05 to $129 \mathrm{~kg} \mathrm{ha}^{-1} \mathrm{yr}^{-1}$ (Table 5). The $\mathrm{S}$ input varied from 5.50 to $44.6 \mathrm{~kg}$ $\mathrm{ha}^{-1} \mathrm{yr}^{-1}$. Input of $\mathrm{Zn}$ ranged from 0.14 to $4.14 \mathrm{~kg} \mathrm{ha}^{-1} \mathrm{yr}^{-1}$. Boron input was estimated 0.36 to $3.36 \mathrm{~kg} \mathrm{ha}^{-1} \mathrm{yr}^{-1}$ (Table 5).

Table 5. Total input of N, P, K, S, Zn and $B$ from fertilizer, rainfall and irrigation under wheat-mungbean-T. aman rice cropping system

\begin{tabular}{l|cccccc}
\hline \multirow{2}{*}{ Treatment } & $\mathrm{N}$ & $\mathrm{P}$ & $\mathrm{K}$ & $\mathrm{S}$ & $\mathrm{Zn}$ & $\mathrm{B}$ \\
\cline { 2 - 7 } & $2009-10$ & $2009-10$ & $2009-10$ & $2009-10$ & $2009-10$ & $2009-10$ \\
\hline \multicolumn{7}{c}{$\mathrm{kg} \mathrm{ha}^{-1}$} \\
Control $\left(\mathrm{T}_{1}\right)$ & 0.00 & 0.48 & 9.05 & 5.50 & 0.14 & 0.36 \\
F. practice $\left(\mathrm{T}_{2}\right)$ & 146 & 31.5 & 63.1 & 5.60 & 0.14 & 0.36 \\
AEZ $\left(\mathrm{T}_{3}\right)$ & 162 & 34.5 & 102 & 23.6 & 1.14 & 1.36 \\
$\mathrm{STB}\left(\mathrm{T}_{4}\right)$ & 195 & 57.5 & 129 & 44.6 & 4.14 & 3.36 \\
\hline
\end{tabular}

\section{Apparent nutrients balance}

An apparent nutrient balance was calculated considering the amount of added nutrient through fertilizer, rain, irrigation water minus the amount of nutrient removed by crops. However, the nutrient balance did not account for the addition of $\mathrm{N}$ from rainfall, irrigation water, or gaseous losses or BNF. Apparent balance of N, P, K, S, Zn and B are shown in Fig. $01 \& 02$. The balance was mainly affected by different nutrient management practices. The apparent balance of $\mathrm{N}$ was negative in all the treatments and the nutrient depletion ranged from -55.0 to $-160 \mathrm{~kg} \mathrm{~N} \mathrm{ha}^{-1} \mathrm{yr}^{-1}$. Some researchers supported the results: in rice-maize system in Bangladesh, the apparent nutrient balances have been highly negative for $\mathrm{N}$ (120 to $-134 \mathrm{~kg} \mathrm{ha}^{-1} \mathrm{yr}^{-1}$ ) (Timsina et al., 2010). In case of $\mathrm{P}$ balance which was negative in control treatment $\mathrm{T}_{1}$ and the $\mathrm{P}$ balance was positive ( 8.0 to $25.5 \mathrm{~kg}$ ha $\left.{ }^{1}\right)$ in all the other treatment where $\mathrm{P}$ containing fertilizer was utilized. This evident indicated that $\mathrm{P}$ depletion was fewer amounts as compared added fertilizer (Ishaque et al., 1998). The balance of $\mathrm{K}$ was negative in all the treatments where the $\mathrm{K}$ mining ranged from -65.0 to $-123 \mathrm{~kg} \mathrm{~K} \mathrm{ha}^{-1} \mathrm{yr}^{-1}$. The results confirmed the declining trends in available soil $\mathrm{K}$ in many treatments and they are comparable with many other long-term studies in rice-rice and ricewheat systems of Asia (Ladha et al., 2003).

The negative $\mathrm{S}$ and $\mathrm{Zn}$ balance was observed in control $\left(\mathrm{T}_{1}\right)$ and farmers practice $\left(\mathrm{I}_{2}\right)$ ranged from -3.55 to -6.7 and -0.33 to $-0.45 \mathrm{~kg} \mathrm{ha}^{-1} \mathrm{yr}^{-1}$, respectively. Remaining treatments showed positive balance ranging from 8.80 to 27.0 and 
0.44 to $3.35 \mathrm{~kg} \mathrm{ha}^{-1} \mathrm{yr}^{-1}$, respectively. Some workers are in agreement with these findings. Jahan et al. (2015a) corroborated that the negative balance was observed in control and farmers practice treatments which was -1 to $-8 \mathrm{~kg} \mathrm{~S}$ ha ${ }^{1} \mathrm{yr}^{-1}$ and remaining treatments showed positive balance ranged from 1 to $4 \mathrm{~kg}$ ha ${ }^{1} \mathrm{yr}^{-1}$. Similar result of $\mathrm{Zn}$ was found by Jahan et al. (2015a) in a monocrop cultivation of T.amn rice where -0.08 to $-0.31 \mathrm{~kg} \mathrm{Zn} \mathrm{ha}^{-1} \mathrm{yr}^{-1}$ was found in control and farmers practice and positive balance (1.12 to $1.61 \mathrm{~kg} \mathrm{Zn} \mathrm{ha}^{-1} \mathrm{yr}^{-1}$ ) was found in AEZ and STB treatment. The B balance was found positive ( 0.08 to $\left.2.96 \mathrm{~kg} \mathrm{ha}^{-1}\right)$ in all the treatments. Jahan et al. (2015b) observed that positive B balance ranged from 0.86 to $1.17 \mathrm{~kg} \mathrm{ha}^{-1}$ and negative B balance was -0.01 to $0.07 \mathrm{~kg} \mathrm{ha}^{-1} \mathrm{yr}^{-1}$ in mungbean cultivation.

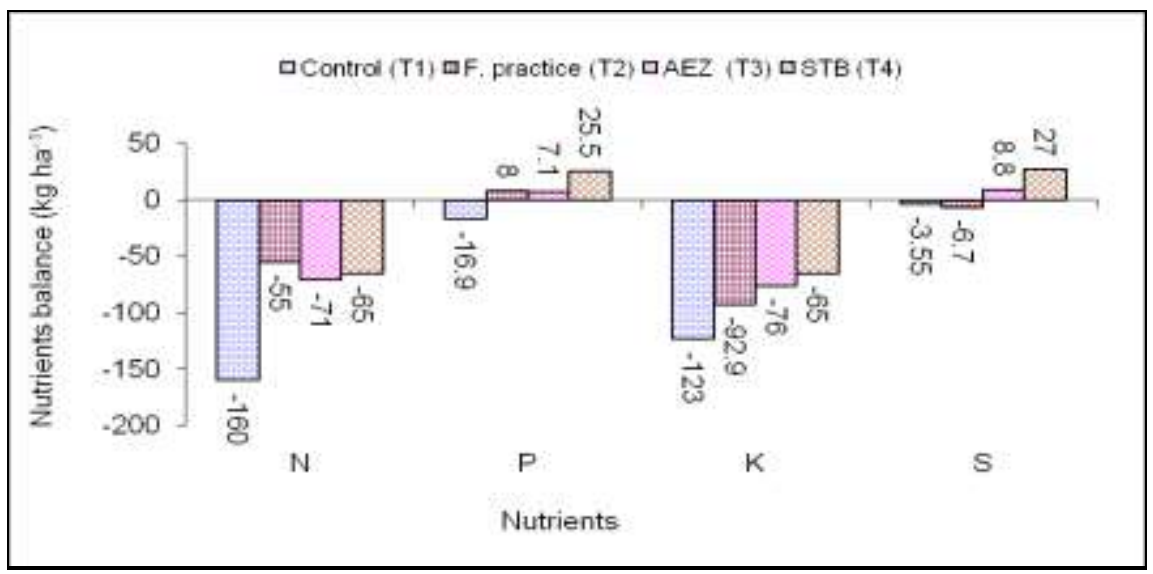

Fig. 01. Apparent nutrient balance of $N, P, K$ and $S$ under wheat-mungbean T.aman cropping rice pattern.

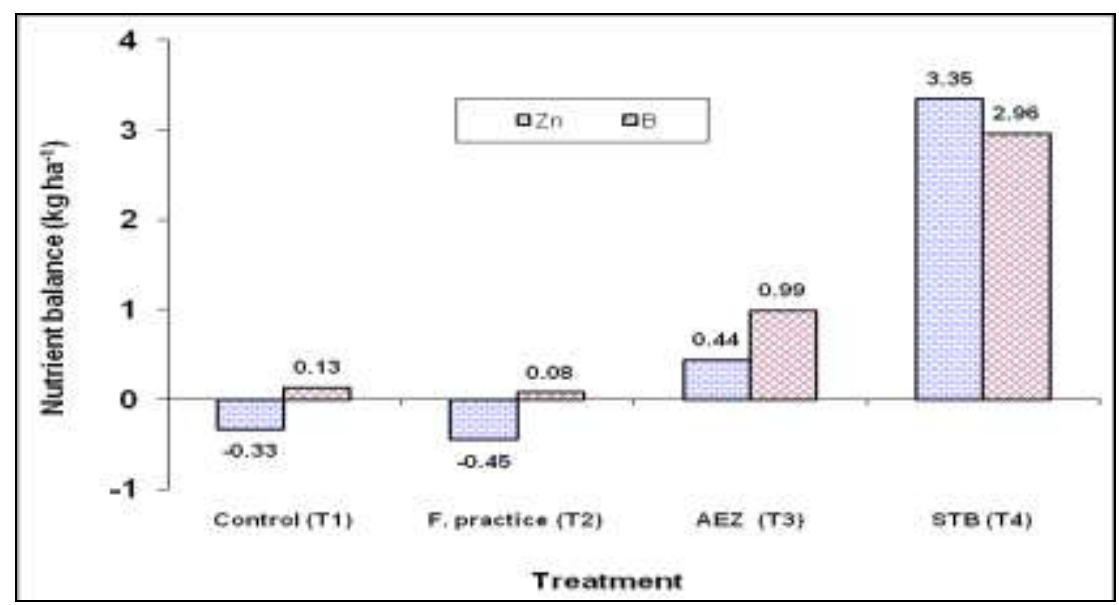

Fig. 02. Apparent nutrient balance of $\mathrm{Zn}$ and $\mathrm{B}$ under Wheat-Mungbean-T.aman cropping pattern. 


\section{Soil Fertility}

Initial soil samples were collected from the experimental field and post harvest soil samples were also collected from each treated plot after two cycles of wheatmungbean-T. aman rice cropping system for analyzing different soil properties viz. soil $\mathrm{pH}$, organic matter, total $\mathrm{N}$ and available $\mathrm{P}, \mathrm{K}, \mathrm{S}, \mathrm{Zn}$ and $\mathrm{B}$. The initial and post harvest soil results are presented in Table 6 . Initially the soil $\mathrm{pH}$ was 6.1, but after completion of two crop cycles and incorporation of mungbean stover and other crop residues in soil, the $\mathrm{pH}$ remained unchanged although minor variation existed. A minor change in soil fertility occurred from initial status due to different fertilizer management practices over two years. Soil test basis fertilizer application $\left(\mathrm{T}_{4}\right)$ tended to maintain the initial fertility or increased slightly (Table 6). The treatment $\mathrm{T}_{4}$ showed an encouraging effect on organic matter, N, P, S, Zn and B only. Such observations are in agreement with the findings of Zaman et al. (1994). Potasium (K) slightly decreased in all plots over the initial status. The results are in agreement with the findings of Timsina and Connor (2001). The available $\mathrm{Zn}$ and B content of the soil slightly decreased when they were not applied, but remained almost static or increase when applied (Table 6).

Table 6. Initial and post soil fertility status after two cycles of wheat-mungbean-T. aman rice cropping system due to different fertilizer management practices

\begin{tabular}{|c|c|c|c|c|c|c|c|c|}
\hline \multirow[b]{2}{*}{ Treatment } & \multirow{2}{*}{$\mathrm{pH}$} & \multirow{2}{*}{$\begin{array}{c}\mathrm{OM} \\
(\%)\end{array}$} & \multirow{2}{*}{$\begin{array}{c}\text { Total N } \\
(\%)\end{array}$} & $\mathrm{K}$ & $\mathrm{P}$ & $\mathrm{S}$ & $\mathrm{Zn}$ & B \\
\hline & & & & Meq. $100 \mathrm{~g}^{-1}$ & \multicolumn{4}{|c|}{$\mu \mathrm{g} \mathrm{g}^{-1}$} \\
\hline Initial status & 6.1 & 1.28 & 0.061 & 0.13 & 15.0 & 17.1 & 1.33 & 0.16 \\
\hline Control $\left(\mathrm{T}_{1}\right)$ & 6.2 & 1.29 & 0.060 & 0.11 & 15.5 & 16.5 & 1.31 & 0.14 \\
\hline F. practice $\left(\mathrm{T}_{2}\right)$ & 6.1 & 1.31 & 0.062 & 0.12 & 16.1 & 16.9 & 1.32 & 0.14 \\
\hline $\operatorname{AEZ}\left(\mathrm{T}_{3}\right)$ & 6.1 & 1.32 & 0.061 & 0.11 & 16.4 & 17.6 & 1.35 & 0.16 \\
\hline $\operatorname{STB}\left(\mathrm{T}_{4}\right)$ & 6.0 & 1.34 & 0.063 & 0.12 & 16.8 & 18.1 & 1.37 & 0.17 \\
\hline
\end{tabular}

\section{Economic analysis}

The gross margin due to treatment $T_{4}$ increased over farmers practice $\left(T_{2}\right)$ for higher crop yield. The highest marginal benefit cost ratio (4.06) was in $\mathrm{T}_{3}$ followed by $T_{4}$ but $T_{3}$ was economically viable due to the cost of production of $\mathrm{T}_{3}$ (Tk. $74248 \mathrm{ha}^{-1} \mathrm{yr}^{-1}$ ) was lower than $\mathrm{T}_{4}$ (Tk. $83967 \mathrm{ha}^{-1} \mathrm{yr}^{-1}$ ) (Table 7). Similar observation was made by Malika et al. (2015) that the highest marginal benefitcost ratio of 3.66 was obtained from $\mathrm{T}_{1}(100 \% \mathrm{RFD})$ which was followed by $\mathrm{T}_{3}$ (75\%RFD + PM $3 \mathrm{tha}^{-1}$ ). Considering the marginal benefit-cost ratio (MBCR) $\mathrm{T}_{3}$ ranked the first. 
Table 7. Economic analysis of wheat-mungbean-T. aman rice cropping pattern affected by different nutrient managements (after completion of two years cycle)

\begin{tabular}{|c|c|c|c|c|c|c|}
\hline \multirow[t]{2}{*}{ Treatment } & $\begin{array}{c}\text { Variable } \\
\text { cost }\end{array}$ & $\begin{array}{l}\text { Gross } \\
\text { return }\end{array}$ & $\begin{array}{l}\text { Added cost } \\
\text { over control }\end{array}$ & $\begin{array}{c}\text { Added } \\
\text { benefit over } \\
\text { control }\end{array}$ & $\begin{array}{l}\text { Gross } \\
\text { margin } \\
\text { over } \\
\text { control }\end{array}$ & \multirow[t]{2}{*}{ MBCR } \\
\hline & \multicolumn{5}{|c|}{$\mathrm{Tk} \mathrm{ha}^{-1} \mathrm{yr}^{-1}$} & \\
\hline Control( $\left.\mathrm{T}_{1}\right)$ & 59875 & 151148 & - & - & - & \\
\hline F. practice $\left(T_{2}\right)$ & 69249 & 185704 & 9374 & 34556 & 25182 & 3.68 \\
\hline $\mathrm{AEZ}\left(\mathrm{T}_{3}\right)$ & 74248 & 209564 & 14373 & 58416 & 44043 & 4.06 \\
\hline $\operatorname{STB}\left(\mathrm{T}_{4}\right)$ & 83967 & 233971 & 24092 & 82823 & 58731 & 3.44 \\
\hline
\end{tabular}

Note: Input prices: Urea $=$ Tk.12 kg-1, T.S.P $=$ Tk.22 kg-1, MoP=Tk.20 kg-1, Gypsum= Tk. $6 \mathrm{~kg}^{-1}$, Zinc sulphate $=$ Tk.120 kg-1, Boric acid $=$ Tk.300 kg-1, Rovral fungicide $=$ Tk.250 $100^{-\mathrm{g}}$, Bavistin fungicide $=$ Tk.200 100-g, Provex fungicide $=$ Tk.3200 $\mathrm{kg}^{-1}$, Ripcord insecticide $=$ Tk.105 $100^{-\mathrm{g}}$, Karate insecticide $=$ Tk.450 500 ${ }^{-\mathrm{ml}}$, Plowing= Tk.1400 ha-1 (one pass), Labour wage $=$ Tk.125 day ${ }^{-1}$, Wheat seed $=$ Tk.25 kg-1 , Mungbean seed $=$ Tk. $60 \mathrm{~kg}^{-1}$, T.aman rice seed $=$ Tk. $35 \mathrm{~kg}^{-1}$.

Output prices: Wheat $=$ Tk. $18.75 \mathrm{~kg}^{-1}$, Mungbean $=$ Tk. $55 \mathrm{~kg}^{-1}$, T.aman rice $=$ Tk.19 $\mathrm{kg}^{-1}$, Wheat straw rate $=\mathrm{Tk} .1 \mathrm{~kg}^{-1}$, Rice straw $=$ Tk.1.25 kg-1.

\section{Conclusion}

Productivity of tested system showed higher through soil test based fertilization. Results clearly indicated that the nutrient uptake by wheat, mungbean and $\mathrm{T}$. aman rice were found to be higher in soil test basis treatment. Nitrogen and K mining occured remarkably from the soil due to different fertilizer management practices. Results of economic and soil fertility suggest that soil test basis fertilization is good for achieving sustainable crop yield.

\section{References}

Ali, A.M., M.R. Alam, M.S.H. Molla and F. Islam. 2010. Crop productivity as affected by fertilizer management options in Boro-T.aman cropping pattern at farmers fields. Bangladesh J. Agril. Res. 35(2), 287-296.

Bremner, J.M. and C.S. Mulvaney. 1982. Total nitrogen, In: Methods of Soil Analysis, Part 2, $2^{\text {nd }}$ Ed., Page, A.L., Miller, R.H., Keeney, D.R., Am. Soc. Agron. Madison, USA. Pp. 599-622.

Debnath, M.R., M. Jahiruddin, M.M. Rahman and M.A. Haque. 2011. Determining optimum rate of boron application for higher yield of wheat in Old Brahmaputra Floodplain soil. J. Bangladesh Agril. Univ. 9(2), 205-210.

Fox, R.L., R.A. Olsen and H.F. Rhoades. 1964. Evaluating the sulphur status of soil by plant and soil test. Soil Sci. Soc. Am. Proc. 28, 243-246. 
Gomez, K.A., A.A. Gomez. 1984. Statistical Procedures for Agricultural Research. International Rice Research Institute, John Wiley \& Sons, NY.

Ishaque, M. 1998. Integrated nutrient management with inorganic fertilizers organic manures for Boro-T.aman rice cropping pattern. Soil Science Division, Bangladesh Agril. Res. Inst. Gazipur. Pp. 113.

Islam, M.R., M.R. Karim, T.M. Riasat and M. Jahiruddin. 1996. Growth and yield of BR11 rice under different levels of sulphur, zinc and boron fertility at two locations of Bangladesh. Thai J. Agric. Sci. 29: 37-42.

Jahan, M.A.H.S., M.A.R. Sarkar, N.C.D. Barma, M.N.A. Mondal and M.N.S. Ferdousi. 2015a. Grain yield, nutrient balance and economics of T. aman rice cultivation as influenced by nutrients management. Bangladesh J. Agril. Res. 40(1), 17-34.

Jahan, M.A.H.S., M.A.R. Sarkar, N.C.D. Barma, M.N.A. Mondal and M.N.S. Ferdousi. $2015 \mathrm{~b}$. Seed yield, nutrient balance and economics of mungbean cultivation as influenced by different nutrients management under AEZ-28. Bangladesh J. Agril. Res. 40(1), 77-93.

Jackson, M.L. 1973. Soil Chemical Analysis. Prentice Hall of India Private Limited, New Delhi. Pp. 498.

Ladha, J.K., D. Dawe, H. Pathak, A.T. Padre, R.L. Yadav, B. Singh, Y. Singh, P. Singh, A.L. Kundu, R. Sakal, N. Ram, A.P. Regmi, S.K. Gami, A.L. Bhandari, R. Amin, C.R. Yadav, E.M. Bhattarai, S. Das, H.P. Aggarwal, R.K. Gupta and R.R. Hobbs. 2003. How extensive are yield declines in long-term rice-wheat experiments in Asia? Field Crops Res. 81, 159-180.

Lindsay, W.L., Norvell, W.A. 1978. Development of a DTPA soil test for Zn, Fe, Mn and Cu. Soil Sci. Soc. Am. J. 42: 421-428.

Nelson, D.W. and L.E. Sommers. 1982. Total carbon, organic carbon and organic matter. In: Methods of Soil Analysis. Part 2. $2^{\text {nd }}$ Edition. Page, A..L, Miller, R.H., Keeney, D.R. Am. Soc. of Agron. Madison, USA. Pp. 539-580.

Olsen, S.R. and L.E. Sommers. 1982. Phosphorus. In: Methods of Soil Analysis, Part 2. $2^{\text {nd }}$ Edition. Page, A.L., Miller, R.H., Keeney, D.R., Am. Soc. Agron. Madison, USA. Pp. 403-427.

Page, A.L., Miller, R.H., Keeney, D.R. (eds.). 1982. Methods of Soil Analysis. Part 2. Chemical and microbiological properties. $2^{\text {nd }}$ Edition. Agronomy series 9 ASA, SSSA. Madison Wis. USA.

Paul Fixen, F. Brentrup, T. Bruu Isema, F. Garcia, R. Norton and S. Zingore. 2014. Nutrient/fertilizer use efficiency : measurement, current situation and trends. IFA, IWMI, IPNI and IPI.

Piper, C.S. 1966. Soil and Plant Analysis. Adelaide University Press, Australia.

Quayyum, M.A., J. Timsina, M.A.H.S. Jahan, R. Ara and D.J. Connor. 2002. Grain Yield and System Productivity for Rice-Wheat-Mungbean and Rice-Wheat-Maize Sequences in Northern Bangladesh. Thai J. Agric. Sci. 35(1), 51-62.

Rahman, MH, Islam MR, Jahiruddin M, Haque MQ. 2011. Economics of fertilizer use in the Maize-Mungbean/Dhaincha-T.aman rice cropping pattern. J. Bangladesh Agril. Univ. 9(1): 37-42. 
Saleque, M.A., J. Timsina, G.M. Panaullah, M. Ishaque, A.B.M.B.U. Pathan, D.J. Connor, P.K. Saha, M.A. Quayyum, E. Humphreys and C.A. Meisner. 2006. Nutrient Uptake and Apparent Balances for Rice-Wheat Sequences. II. Phosphorus. J. Plant Nutr. 28: 157-172.

Shrestha, R.K. and J.K. Ladha. 2001. Nutrient balances in a rice-vegetable system: a case study of an intensive cropping system in Ilocos Norte, the Philippines. International Workshop on Nutrient Balances for Sustainable Agricultural Production and Natural Resource Management in Southeast Asia. Bangkok, Thailand.

Singh G.B. and D.V. Yadav. 1992. INSS in sugarcane and sugarcane based cropping system. Fert. News. 37(4): 15-20.

Timsina, J. and D.J. Connor. 2001. Productivity and management of rice-wheat cropping system: Issues and Challenges. Field Crop Research. 69: 7-11.

Timsina, J., G.M. Panaullah, M. Saleque, M. Ishaque, A.B.M.B.U. Pathan, M.A. Quayyum, D.J. Connor, P.K. Saha, E.C. Humphreys and C.A. Meisner. 2006. Nutrient Uptake and Apparent Balances for Rice-Wheat Sequences. I. Nitrogen. J. Plant Nutr. 29: 137-155.

Timsina, J., L.J. Mangi and K. Majumdar. 2010. Rice-maize systems of South Asia: current status, future prospects and research priorities for nutrient management. Plant Soil. 335: 65-82.

Tirol-Padre, A., J.K. Ladha, A.P. Regmi, A.L. Bhandari and K. Inubushi. 2007. Organic amendments affect soil parameters in two long-term rice-wheat experiments. Soil Sci. Soc. Am. J. 71: 442-52.

Yadvinder-Singh, Bijay-Singh, and J. Timsina. 2005. Crop residue management for nutrient cycling and improving soil productivity in rice-based cropping systems in the tropics. Advances in Agronomy. 85: 269-407.

Zaman, M.W., S.H. Rahman, B. Moriza and S. Ahmed. 1994. Phosphorus and zinc interaction in rice grain. Progressive Agriculture. 5(2): 273-278. 